\title{
PERSEPSI KELOMPOK LANSIA TERHADAP KESEDIAAN MENERIMA VAKSINASI COVID-19 DI WILAYAH RURAL INDONESIA
}

\author{
Ristina Rosauli Harianja ${ }^{1}$, Tris Eryando ${ }^{2}$ \\ Program Pascasarjana Kesehatan Masyarakat, Fakultas Kesehatan Masyarakat ${ }^{1}$ \\ Departemen Biostatistik dan Ilmu Kependudukan Fakultas Kesehatan Masyarakat ${ }^{2}$ \\ Universitas Indonesia \\ rosaulli_ristinn@yahoo.co.id ${ }^{1}$, triseryando@ui.ac.id ${ }^{2}$
}

\begin{abstract}
Corona Virus Disease (COVID-19) is an infectious disease caused by a type of coronavirus (type beta $(\beta-C o V)$. Since the government announced the Covid-19 vaccination in Indonesia, people have been faced with various dilemmas regarding the implementation of this policy. Looking at community activities on social media, there are still calls from groups who reject the Covid-19 vaccine. Therefore, researchers are interested in seeing how the perception of the elderly group regarding their willingness to receive the COVID-19 vaccine is reviewed using the Health Belief Model This study uses a research design qualitative with in-depth interview technique. The triangulation of sources in this study was the family as a companion for the elderly and the vaccinator of the puskesmas. Research ethics uses the Helsinki declaration and the analysis uses thematic analysis with the concept of the Health Belief Model. The results of this study are; The elderly have a good perception of vulnerability, the elderly know that the fatality of the COVID-19 virus can cause death, the elderly understand the benefits of the COVID-19 vaccine, but the elderly are still unsure about the side effects of the vaccine based on the experiences of the closest people they see. So that a more massive role of health workers is needed in providing information and socialization to the elderly to be able to influence their acceptance behavior towards the COVID-19 vaccine program.
\end{abstract}

Keywords $\quad$ :COVID-19, Elderly, Health Belief Model, Vaccines

\begin{abstract}
ABSTRAK
Corona Virus Deisease (COVID-19) adalah penyakit menular yang disebabkan oleh jenis corona virus (tipe beta $(\beta-\mathrm{CoV})$. Situasi ini tentu saja sangat berpengaruh terhadap berbagai kelompok rentan, Tata laksana virus COVID-19 mendapatkan rekomendasi dari WHO untuk tindakan pencegahan penyebaran COVID-19 antara lain adalah melakukan handy hygiene, social distancing,memakai masker,dan meningkatkan daya tahan tubuh. Selain itu untuk meningkatkan system pertahanan tubuh melawan virus dapat juga dilakukan dengan pemberian vaksin. Sejak pemerintah mengumumkan vaksinasi COVID-19 di Indonesia, masyarakat telah dihadapkan dengan berbagai dilema pemberlakuan kebijakan ini. Melihat aktivitas masyarakat di media sosial media, masih ditemukan seruan kelompok yang menolak vaksin COVID-19 salah satunya ialah kelompok lansia. Karena itu peneliti merasa tertarik untuk melihat bagaimana persepsi kelompok Lansia terhadap kesediaan menerima vaksin COVID-19 ditinjau dengan Health Belief Model. Penelitian ini menggunakan desain penelitian kualitatif dengan wawancara mendalam. Triangulasi sumber dalam penelitian ini adalah keluarga sebagai pendamping lansia dan petugas vaksinator puskesmas. Etika penelitian menggunakan deklarasi Helsinki dan analisis menggunakan analisis tematik dengan konsep Health Belief Model. Pada penelitian ini didapatkan hasil; Lansia memiliki persepsi kerentanan yang baik, Lansia tahu kefatalan virus COVID-19 dapat menyebabkan kematian, Lansia mengerti manfaat dari vaksin COVID-19, akan tetapi lansia masih ragu dengan efek samping dari vaksin tersebut berdasarkan pengalaman orang terdekat yang mereka lihat. Sehingga sangat dibutuhkan peran tenaga kesehatan yang lebih massif dalam memberikan informasi dan sosialisasi kepada lansia untuk dapat mempengaruhi perilaku penerimaan mereka terhadap program vaksin COVID-19.
\end{abstract}

Kata Kunci : COVID-19, Lansia, Health Belief Model, Vaksin 


\section{PENDAHULUAN}

Corona Virus Deisease (COVID-19) adalah penyakit menular yang disebabkan oleh jenis coronavirus (tipe beta $(\beta-\mathrm{CoV})$ yang dinamakan SARS-CoV-2 (Guo et al., 2020; Zhou et al., 2020; Zhu et al., 2020). World Health Organization (WHO), menetapkan wabah COVID-19 atau virus corona (SARS CoV-2) menjadi pandemi global. Situasi ini tentu saja sangat berpengaruh terhadap berbagai kelompok rentan, diantaranya perempuan, orang lanjut tua, remaja, pemuda, dan anak-anak, para penyandang cacat, penduduk asli, dan minoritas mengalami marjinalisasi sosialekonomi tingkat tertinggi (Bardosh, 2017).

Tata laksana virus COVID-19 mendapatkan rekomendasi dari WHO untuk tindakan pencegahan penyebaran COVID-19 antara lain adalah melakukan handy hygiene, social distancing,memakai masker,dan meningkatkan daya tahan tubuh. Selain itu untuk meningkatkan system pertahanan tubuh melawan virus dapat juga dilakukan dengan pemberian vaksin. Vaksin adalah salah satu cara yang paling efektif dan ekonomis untuk mencegah penyakit menular. Sehingga diperlukan untuk membuat pengembangan vaksin agar lebih efektif untuk melemahkan infeksi virus corona. Sejauh ini lebih dari 40 perusahaan farmasi dan lembaga akademis di seluruh dunia telah meluncurkan program pengembangan vaksin mereka untuk melawan virus Covid-19. (Makmun dan Hazhiyah 2020).

Indonesia telah berupaya secara maksimal mengatasi tantangan-tantangan yang ada. Dalam Keputusan Presiden Nomor 18/2020 yang dikeluarkan pada tanggal 3 September 2020 Presiden telah menetapkan pembentukan tim pengembangan vaksin COVID-19 di bawah pengawasan Menteri Koordinator Bidang Perekonomian.1 Lebih lanjut lagi, pada tanggal 6 Oktober 2020, Presiden menandatangani dan mengeluarkan Peraturan Presiden (Perpres) tentang pengadaan vaksin dan pelaksanaan program vaksinasi untuk menanggulangi pandemi COVID-19 (Kemkes, 2020).

Sejak pemerintah mengumumkan vaksinasi COVID-19 di Indonesia, masyarakat telah dihadapkan dengan berbagai dilema pemberlakuan kebijakan ini. Melihat aktivitas masyarakat di media sosial media, masih ditemukan seruan kelompok yang menolak vaksin COVID19. Bahkan, terdapat 49,9 persen dari total 601 responden menolak untuk menjadi penerima vaksin COVID-19 pertama. Pemerintah Indonesia memperkirakan akan menerima 30 juta dosis vaksin pada akhir tahun 2020 melalui perjanjian bilateral dengan berbagai produsen vaksin dan tambahan 50 juta dosis pada awal tahun 2021. Saat vaksin yang aman tersedia, Pemerintah Indonesia berencana segera melaksanakan vaksinasi sebagaimana diamanatkan Perpres yang dikeluarkan pada awal bulan Oktober (Kemkes, 2020).

Semua populasi memiliki risiko yang sama untuk tertular, namun kelompok orang tua dan orang dengan kondisi imunitas yang rendah lebih rentan untuk tertular dengan dampak yang lebih serius. Sebagian besar pasien memiliki gejala ringan dan kematian. Mayoritas kematian terjadi pada pasien berusia 60 dan lebih, dan menderita penyakit dasar seperti hipertensi, penyakit kardiovaskular, dan diabetes (Novel C. P. E. R. E., 2020) .

Tidak semua golongan masyarakat langsung dapat diberikan vaksinasi hal ini berdasarkan Surat Edaran Nomor HK.02.02/I/368/2021 tentang Pelaksanaan Vaksinasi COVID-19 pada Kelompok Sasaran Lansia, Komorbid, dan Penyintas COVID-19 serta Sasaran Tunda yang dikeluarkan oleh Direktorat Jenderal Pencegahan dan Pengendalian Penyakit Kemenkes (Kemenkes, 2021).

Kondisi lansia yang tergolong rentan, membuat lansia sebagai salah satu kelompok sasaran utama sebagai prior/itas 
penerima vaksin. Oleh karena itu peneliti ingin melihat bagaimana persepsi yang dirasakan oleh kelompok lansia sebelum mendapatkan imunisasi vaksin COVID-19 ini ditinjau dengan Health Belief Model dalam kerangka konsep berikut. Konsep dasar dari teori HBM ini diharapkan dapat menggambarkan perilaku lansia yang ditentukan oleh keyakinan atau persepsi personal individu mengenai suatu penyakit dan strategi pemberian vaksin untuk menurunkan angka kesakitan akibat penyakit tersebut. Sehingga hasil penelitian ini diharapkan dapat menjadi studi pendahuluan bagi penelitian isu yang sama dengan analisis lanjutan untuk menggali persepsi kelompok Lansia terhadap penerimaan vaksin COVID-19.

\section{METODE}

Penelitian ini menggunakan pendekatan riset kualitatif dimana pendekatan ini dapat menggali persepsi kelompok Lansia terhadap penerimaan vaksin COVID-19. Penelitian dilakukan pada April 2021 dengan memanfaatkan teknologi informasi berbasis daring aplikasi whatsapp karena situasi pandemik Subjek penelitian dipilih dengan metode purposive sampling. Populasi target penelitian adalah kelompok lansia yang berjumlah 6 orang.

Pengumpulan data menggunakan teknik wawancara mendalam (in-depth interview) dengan menggunakan teknik wawancara secara semi terstruktur. Pedoman wawancara telah dilakukan uji coba terlebih dahulu kepada lansia yang memiliki kriteria yang sama.

Triangulasi dalam penelitian ini menggunakan triangulasi sumber yakni melibatkan satu orang petugas vaksinasi puskesmas dan dua pendamping lansia. Analisis data yang dilakukan dengan menggunakan analisis tematik dengan bantuan matriks penelitian.

Etik penelitian menggunakan Deklarasi Helsinki sebagai pernyataan prinsip-prinsip etika untuk penelitian medis yang melibatkan subyek manusia. Sebelum dilakukan pengambilan data, informan diberikan informed concent dan menandatangani lembar presetujuan menjadi informan.

\section{HASIL}

Proses pengumpulan data dilakukan terhadap 6 informan yang telah menyatakan bersedia untuk diwawancarai, serta untuk proses triangulasi sumber didapatkan 1 orang informan petugas vaksinator puskesmas dan 2 orang keluarga/pendamping lansia. Dari hasil wawancara didapatkanlah data sebagai berikut:

\section{Persepsi Kerentanan}

Seluruh informan memiliki persepsi kerentanan yang cukup baik. Salah satu informan menjelaskan bahwa dirinya merupakan kelompok yang rentan untuk mengalami sakit atau terjangkit penyakit COVID 19.

Pernah mendengar informasi
tentang COVID-19 dari TV.
Lansia kan lebih lemah jadi lebih
mudah tertular, makanya dihimbau
untuk tetap dirumah, tidak
berkerumun, menggunakan masker
ketika keluar, menjaga jarak
dengan orang lain, dan mengikuti
kegiatan vaksin.(L1-54thn)

Namun disisi lain dapat dilihat dari hasil wawancara dengan petugas vaksinator meskipun merasa rentan tetapi sebagian dari lansia tampak kurang menaruh perhatian dan kepercayaan mereka terhadap aturan yang telah dibuat oleh pemerintah dengan mengabaikan himbauan untuk di suntik vaksin.

iya memang beberapa lansia mengaku takut kalau sampai kena, tapi mereka lebih takut lagi kalau nanti efeknya setelah di suntik malah jadi tambah sakit. Jadinya 
meskipun sudah banyak liat dan dengar informasinya tapi tetap harus di jemput bola juga rumahkerumah (N2)

\section{Persepsi Keparahan}

Semua informan mengetahui bahwa COVID-19 ini berbahaya dan dapat menyebabkan kematian terutama untuk kelompok rentan seperti Lansia. Informan percaya bahwa penyakit COVID-19 ini memang ada dan akan sangat fatal efeknya. Ditambah lagi dengan beberapa kerabat terdekat pun sudah banyak yang meninggal diakibatkan oleh virus COVID19 ini.

Tentu takutlah namanya kematian pasti semuanya takut. Tetangga sekitar rumah dan saudarasaudara saya juga sudah banyak yang meninggal katanya kena corona. (L4-52thn)

Namun meskipun begitu beberapa informan yaitu L3, L5 dan L6 mengaku bahwa mereka tetap enggan dan takut untuk di suntik vaksin dikarenakan pengalaman mereka melihat salah satu pejabat dilingkungan rumah mereka yang mengalami efek samping pasca vaksinasi.

Kalau nanti habis di vaksin ternyata malah tambah sakitnya gimana. Jadi ya mikir juga karena pak $R T$ juga habis vaksin langsung demam tinggi diberita juga katanya ada yang sampai meninggal. Kalau saya sakit mereka mau tanggung jawab tidak (L6-52thn)

Dari pernyataan tersebut terlihat jelas bahwa sosialisasi terkait efek reaksi tubuh dalam memproses antibodi sehingga kerap menimbulkan beberapa gejala tersebut belum sampai ke sebagian informan.

Persepsi Manfaat
Dari wawancara ditemukan juga bahwa sebenarnya informan merasakan bahwa vaksin Covid ini akan memberikan dampak positif bagi diri mereka. Terlepas dari sifatnya yang wajib dan seperti memaksa tetapi sebagian informan mengaku tidak menolak untuk disuntik vaksin.

kita kan kelompok rentan namanya juga ikhtiar jadi kita usahakan saja gimana supaya sehat terus. Kalau katanya musti vaksin ya sudah ikut saja yang penting yang terbaik (L2-57thn)

Namun di sisi lain, beberapa informan bahkan harus di ancam terlebih dahulu agar mau patuh ikut kegiatan vaksinasi. Terlepas dari manfaatnya untuk melindungi, keluarga dari salah satu informan mengaku bahwa harus memaksa orang tuanya agar mau di vaksin dikarenakan urusan birokrasi diperkirakan akan sangat sulit dilakukan jika orangtuanya tidak bersedia dan belum menerima suntikan vaksin.

Sempat bandel pas di suruh vaksin banyak alasannya. Tapi karna rencana mau berangkat Haji di tahun ini. Kalau tidak punya surat vaksin tidak bisa kemana-mana akhirnya menurut juga sih. Padahal kan vaksin bagus untuk kesehatan mamak biar tidak parah kalau amit-amit nanti kena. (N1)

\section{Persepsi Hambatan}

Dibalik antusisasme beberapa lansia yang mengaku ingin dan bersedia untuk disuntik namun tentu saja hal ini dipengaruhi oleh beberapa kondisi terutama kondisi kesehatan dari informan. Kondisi ini tentu tidak dapat dilanjutkan untuk di vaksin karena akan berbahaya jika tetap dipaksakan.

Namanya juga orang tua, kemarin saja saya disuruh pulang karena tidak lolos tes dari petugasnya karena tekanan darah nya tinggi. 
Ya mau bagaimana lagi dari pada nanti kenapa-kenapa (L3-55thn)

Informasi dari informan tersebut diamini oleh petugas vaksinator yang meyatakan bahwa memang untuk proses skrining nya sendiri beberapa lansia dinyatakan tunda dulu untuk di suntik sampai memang dinyatakan benar-benar siap untuk menghindari hal-hal yang tidak diinginkan.

\section{Iya kalau kita biasanya sesuai aturan saja, kalau tidak lolos kriteria kita juga tidak berani mau ngasih vaksinnya (N2)}

Meskipun tim vaksinator pun menyatakan meskipun terkadang lansia kerap menajadikan alasan kesehatan untuk tidak di vaksin namun mereka masih tetap berusaha mencari jalan keluar lain termasuk salah satunya yaitu dengan berkoordinasi dengan instansi dan pejabat lain demi kelancaran proses vaksinasi ini.

Sempat banyak yang tidak
bersedia banyak alasannya
katanya sakit lah, pusinglah,
demam lah sampai ada yang
bersembunyi pas pendataan tapi
kita usahakan jemput bola di tiap
kelurahan. Kita skrinning di
rumah masing-masing jika
memenuhi kriteria agar bisa
langsung kita vaksin. Kita juga
koordinasi sama pemuda dan
polsek setempat jadi bisa cepat
mencapai target. (N2)

Tanda-tanda/ sinyal untuk melakukan tindakan

Puskesmas sebagai pos utama telah memberikan layanan vaksin dalam memberikan layanan bisa dikategorikan sebagai baik. Informasi tersebut didapatkan dari wawancara kepada tim vaksinator Puskesmas. Mereka menyatakan bahwa mereka telah memberikan sosialisasi bahkan hingga unit terkecil dalam lingkungan masyarakat demi tercapainya kegiatan vaksinasi pada lansia ini.
sepertinya sudah mulai bagus jika dilihat dari jumlah kunjungan yang ikut vaksin dosis pertama yang cukup banyak. Apalagi kita sudah koordinasi dengan banyak pihak dari tingkat RT, Kelurahan, posyandu lansia. kita juga sudah mengerahkan kader-kader supaya aktif mendata, mensosialisasi para lansia untuk ikut kegiatan vaksinasi ini. Kita berharap untuk boosternya juga akan se banyak ini $\operatorname{sih}(N 2)$

\section{Self-efficacy}

Ketakutan terhadap penyakit COVID19 ini lebih besar dibanding ketakutan terhadap suntik vaksinnya, di mana hal ini tampak dari tindakan mereka yang pada akhirnya tetap mematuhi kebijakan pemerintah untuk disuntik vaksinasi.

Saya sih yakin saja kalau vaksin ini bermanfaat dan akan menyelamatkan saya dari virus Corona ini. Tidak mungkin lah pemerintah ingin masyarakat terutama lansia seperti saya ini celaka kan. Jadi ikut saja lah (L257thn)

Namun dari informasi yang didapat dari salah satu pendamping lansia, ternyata masih ada informan yang meskipun merasa rentan dan takut namun tetap tidak berkenan untuk di suntikkan vaksin. dari pernyataan keluarga yang tinggal dengan informan masih ada lansia yang mengungkapkan kekhawatiran untuk di vaksin dan mempersoalkan terkait efek samping vaksin, serta sudut pandang vaksin dari sisi Agama.

$$
\begin{aligned}
& \text { Bapak saya sudah saya } \\
& \text { suruh tapi tetap tidak mau. } \\
& \text { Katanya wong sudah tua begini } \\
& \text { kalau mau meniggal ya meninggal }
\end{aligned}
$$


saja. Dari pada nanti malah jadi tambah sakit. Apalagi belum tenttu Halal juga katanya ya sudah lah nurut saja untuk di tunda dulu sambil pelan-pelan nanti di rumah saya pengaruhi lagi. (N1)

\section{PEMBAHASAN}

Saat ini vaksinasi menjadi prioritas nasional dan standar pemerintah daerah dalam menerapkan protokol kesehatan. Penelitian terkait Persepsi penerimaan vaksin COVID-19 pada lansia salah satunya dapat menggunakan teori health belief model sebab pada teori ini dijelaskan bagaimana perilaku bersedia untuk terlibat dalam Tindakan pencegahan atau promosi kesehatan dipengaruhi oleh 6 konsep yaitu: persepsi tentang keseriusan masalah yang dihadapi, persepsi tentang kerentanan, persepsi tentang manfaat dan hambatan, persepsi tentang ancaman, efikasi diri, dan cues to action. Dari 6 konsep ini juga dipengaruhi oleh modifying variables seperti demographic variables (tempat tinggal, umur, dan lainnya).

\section{Persepsi Kerentanan}

Merasa rentan adalah komponen intrinsic dan berpotensi mempengaruhi persepsi dari informan terhadap keberhasilan penerimaan vaksin COVID19. Hasil penelitian menunjukan bahwa informan telah memiliki persepsi kerentanan yang baik. Hal ini dikarenakan seluruh informan mendapatkan pengetahuan yang diperoleh dari informasi terkait vaksin COVID-19 melalui media televisi. Hal ini sama halnya dengan rekomendasi yang diberikan oleh Kemenkes, ITAGI, UNICEF, dan WHO, dan dapat dipertimbangkan guna memastikan keberhasilan pelaksanaan vaksinasi COVID-19. Beberapa langkah perlu segera dilakukan, seperti menyediakan informasi tentang keamanan dan keefektifan vaksin COVID-19 untuk publik lewat berbagai media (Kemkes, 2020).

Temuan ini sama dengan penelitian yang telah dilakukan oleh Hooker dan Leask (Hooker dan Leask, 2020) Pelajaran dari wabah penyakit menular sebelumnya dan keadaan darurat kesehatan masyarakat, termasuk HIV, H1N1, SARS, MERS, dan Ebola, mengingatkan kita bahwa sumber informasi dan panduan terpercaya sangat penting untuk pengendalian penyakit.

Informasi yang tepat, jelas, dan konsisten yang diterima oleh masyarakat dapat membantu untuk membangun kepercayaan masyarakat terhadap informasi terkait dengan kerentanan ini. Sehingga dapat mempermudah untuk membangun kepercayaan publik terhadap program vaksin ini.

\section{Persepsi Keparahan}

Dalam penelitian ini sebagian responden takut jika harus menerima kefatalan akibat terserang virus COVID-19 namun disisi lain informan pun takut apabila ternyata vaksin tersebut akan menjadi boomerang dan berdampak burk bagi kesehatan mereka. Isu-isu negative terkait efek samping negative vaksin yang diterima tentu mempengaruhi persepsi informan untuk kesediaan di vaksin.

Hasil serupa terkait Keberadaan isu negatif tentang vaksin sehingga menyebabkan ada responden yang tidak setuju untuk divaksin sama seperti penelitian yang dlakukan di Gresik yang menyatakan bahwa adanya isu Danramil Kebomas di meninggal yang diakibatkan vaksin COVID-19, penjelasan langsung yang disampaikan oleh Kasad TNI AD, Brigadir Jenderal Supriyono mengklaim yang menyebutkan bahwa Danramil Kebomas Gresik meninggal dunia akibat disuntik vaksin COVID-19 adalah tidak benar. Faktanya Danramil Kebomas, Mayor Kav Gatot Supriyono meninggal dunia dengan indikasi serangan jantung dan belum pernah divaksin. (Sukmasih, 2020) 


\section{Persepsi Manfaat}

Penelitian terkait survei untuk melihat sikap individu terhadap vaksin COVID-19 di masa depan, menyatakan bahwa mereka bersedia untuk divaksin alasannya karena mereka berpikir bahwa vaksin tidak hanya untuk dirinya sendiri atau anak-anaknya tetapi juga untuk melindungi kesehatan orang-orang disekitarnya. Alasan kedua yaitu vaksin melindungi dari penyakit COVID-19. Sama halnya dalam penelitian yang dilakukan oleh Akarsu dimana dalam penelitian ini juga peneliti tersebut menyelidiki pemikiran dan sikap individu terhadap vaksin COVID-19. Meskipun mereka mesepakat bahwa vaksin COVID-19 penting namun 8,6\% dari peserta survey menyatakan jika vaksin untuk infeksi COVID-19 dikembangkan mereka tetap tidak akan divaksinasi (Akarsu et al. 2021). Tingkat pengetahuan berpengaruh terhadap pemikiran dan sikap individu terhadap vaksin COVID-19. Dengan tingkat pengetahuan yang tinggi maka cara berfikir informan terkait penyuntikan vaksinasi untuk dirinya pun semakin meningkat

\section{Persepsi Hambatan}

Komite Penasihat Ahli Imunisasi Nasional telah menyampaikan bahwa vaksinasi COVID-19 dapat diberikan pada kelompok usia 60 tahun keatas, komorbid, penyintas COVID-19 dan Ibu menyusui dengan terlebih dahulu dilakukan anamnesa tambahan.

Dalam surat edaran (SE) Kementerian Kesehatan RI mengirimkan kepada Kepala Dinas Kesehatan Provinsi, Kabupaten / Kota terkait pelaksanaan vaksinasi COVID-19 yang berisi perihal pelaksanaan vaksinasi bagi kelompok komorbid dengan ketentuan yang harus dipenuhi dengan tetap mengikuti petunjuk teknis pelaksanaan vaksinasi COVID-19. (Kemkes, 2021).
Jadi pelaksanaan pemberian vaksinasi bagi kelompok Lansia yang masuk kelompok Komorbid sebenarnya masih dapat divaksinasi sepanjang belum ada komplikasi akut.

\section{Tanda-Tanda/ Sinyal Untuk Melakukan Tindakan}

Tenaga kesehatan memegang peranan penting dalam memberikan penyuluhan bagi masyarakat sebagai media komunikasi yang paling dapat dipercaya saat ini terkait program vaksinasi COVID19. Dalam hal ini Puskesmas sebagai pos utama lah sebagai ujung tombak dalam memberikan layanan vaksin maupun juga memberikan layanan konseling serta pendidikan kesehatan bagi masyarakat.

Survey yang dilakukan oleh UNICEF dan Kemkes (Kemkes, 2021) menyatakan bahwa tenaga kesehatan dan staf medis dianggap paling dipercaya (57\%) dalam membimbing responden yang masih ragu supaya memutuskan untuk bersedia atau menolak divaksin. Selain itu, anggota keluarga merupakan pilihan kedua responden yang ingin berkonsultasi dengan orang lain.

\section{Self-Efficacy}

Rendahnya tingkat penerimaan vaksin COVID-19 ini bisa menjadi masalah utama dalam upaya global untuk mengendalikan pandemic COVID-19 yang saat ini terjadi. Mengatasi keragu-raguan dalam kepuasan diri, kenyamanan dan kepercayaan dalam melakukan vaksin COVID-19 ini dapat membangun kepercayaan dalam upaya vaksinasi COVID-19 (Malik, 2021).

\section{KESIMPULAN}

Dari hasil penelitian ini, dapat disimpulakan bahwa pengetahuan Lansia Menanggapi tentang vaksin COVID-19 berada pada kategori baik, namun karena belum diiringi oleh penyuluhan yang 
adekuat sehingga masih ada Lansia yang memiliki persepsi yang buruk yang ternyata berpengaruh terhadap perilaku penerimaan mereka terhadap pelaksanaan program vaksinasi COVID-19 ini. Hasil temuan ini menjadi informasi yang baik bagi pemerintah dalam program mensosialisasikan lebih lanjut lagi mengenai vaksinasi COVID-19. Rata-rata responden yang tidak setuju divaksin karena takut dengan efek samping, dari data tersebut maka diharapkan pemerintah lebih melakukan sosialisasi yang lebih masif dengan melibatkan semua pihak baik secara langsung ataupun dengan media.

\section{UCAPAN TERIMAKASIH}

Bersyukur atas Tuhan Yang Maha Esa, yang telah memberikan rahmat serda hidayahnya kepada peneliti untuk dapat menyelesaikan penelitian ini dalam kondisi baik

\section{DAFTAR PUSTAKA}

Akarsu, Büşra, Dilara Canbay Özdemir, Duygu Ayhan Baser, Hilal Aksoy, İzzet Fidanc1, and Mustafa Cankurtaran. (2021) —While Studies on COVID-19 Vaccine Is Ongoing, the Public's Thoughts and Attitudes to the Future COVID-19 Vaccine.l International Journal of Clinical Practice https://doi.org/10.1111/ijcp.13891.

Arikunto, S. (2006) Prosedur Penelitian (Suatu Pendekatan Praktik). Jakarta : Rineka Cipta

Bardosh, K.L., Ryan, S.J., Ebi, K. et al. (2017) Addressing vulnerability, building resilience: community-based adaptation to vector-borne diseases in the context of global change. Infect Dis Poverty 6, 166. https://doi.org/10.1186/s40249-0170375-2

Bungin, Burhan. (2003) Analisis Data Penelitian Kualitatif . Jakarta: PT Raja

\section{Grafindo Persada.}

Guo, Y.-R., Cao, Q.-D., Hong, Z.-S., Tan, Y.-Y., Chen, S.-D., Jin, H.-J., ... Yan, Y. (2020) The origin, transmission and clinical therapies on coronavirus disease 2019 (COVID-19) outbreak an update on the status. Military Medical Research, 7(1), 1-10. https://doi.org/10.1186/s40779-02000240-0

Hooker, Claire, and Julie Leask. (2020) -Risk Communication Should Be Explicit About Values. A Perspective on Early Communication During COVID-19.| Journal of Bioethical Inquiry, no. Slovic 1987. https://doi.org/10.1007/s11673-02010057-0.

Kemenkes (2020) Pedoman Pencegahan dan Pengendalian Corona Virus Disease (COVID-19)

Kemenkes (2020) Survei Penerimaan Vaksin COVID-19 di Indonesia

Kemenkes (2021). Pedoman Pelaksanaan Vaksinasi COVID-19 Pada Kelompok Sasaran Lansia, Komorbid dan Penyintas COVID-19 Serta Sasaran Tunda

Makmun, Armanto, and Siti Fadhilah Hazhiyah. (2020) - Tinjauan Terkait Pengembangan Vaksin Covid 19.॥ Molucca Medica https://doi.org/10.30598/molmed.2020. v13.i2.52.

Novel C. P. E. R. E. (2020) The Epidemiological Characteristics of An Outbreak of 2019 Novel Coronavirus Diseases (COVID-19) in China. Zhonghua Liu Xing Bing Xue Za Zhi= Zhonghua Liuxingbingxue Zazhi, 41(2), 145-151. https://doi.org/10.3760/cma.j.issn.0254 $-6450.2020 .02 .003$

Sallam, Malik, and Azmi Mahafzah. (2021) -Molecular Analysis of Sars-Cov-2 Genetic Lineages in Jordan: Tracking the Introduction and Spread of Covid-19 UK Variant of Concern at a Country Level.\| 
Pathogens.

https://doi.org/10.3390/pathogens1003 0302.

Zhou, P., Yang, X. Lou, Wang, X. G., Hu, B., Zhang, L., Zhang, W., ... Shi, Z. L. (2020) A Pneumonia Outbreak Associated With A New Coronavirus of Probable Bat Origin. Nature, 579(7798), 270-273. https://doi.org/10.1038/s41586-020-

\section{2-7}

Zhu, N., Zhang, D., Wang, W., Li, X., Yang, B., Song, J., ... Tan, W. (2020) A Novel Coronavirus From Patients With Pneumonia In China, 2019. New England Journal of Medicine, 382(8), 727-733.

https://doi.org/10.1056/NEJMoa20010 17 